Buana Sains Vol 18 No 1: 57 - 66, 2018

\title{
PENGARUH LIMBAH INDUSTRI AGAR-AGAR RUMPUT LAUT TERHADAP SIFAT KIMIA TANAH DAN PERTUMBUHAN TANAMAN JAGUNG PADA INCEPTISOL KECAMATAN PANDAAN PASURUAN
}

\author{
Bambang Siswanto dan Widowati \\ Program Studi Agroteknologi, Fakultas Pertanian, Universitas Tribhuwana Tunggadewi
}

\begin{abstract}
Inceptisol is one type of land order that is widely spread in Indonesia. Its distribution reaches approximately 52.0 million hectares (Kasno, 2009). Inceptisol is widely used as an intensive farm because its management is less precise, then most Inceptisol fertility rate becomes low. This is often shown by soil acidity, organic matter content, and low nitrogen, to improve such properties one of which can use the addition of organic matter. The problem that often arises is the high cost of organic fertilizer.

Seaweed industry waste is a source of organic material that has not been widely utilized. Of the total raw materials processed, there is 65 to 70 percent of industrial products produced by the seaweed industry waste every day (Mandela. 2010). Usually, these side products are only left to accumulate at the landfill site. Seaweed industry waste has the potential to be used as a source of soil organic matter because the organic material content of products of seaweed industry reaches $6.4 \%$ (Afif, 2011). The addition of nutrients to the application of inorganic materials is considered as an alternative step in increasing crop productivity. Based on the description above, it is necessary to conduct research to utilize the waste of seaweed industry, to get high corn production in Inceptisol. The objectives of this research are: (1) To know the effect of seaweed industrial solid waste on soil chemical properties Inceptisol and (2) growth of corn crop.

The research was conducted in the greenhouse, while for the analysis of soil samples and the waste of seaweed industry was conducted in soil chemistry and soil physics laboratory, Department of Soil Science, Faculty of Agriculture, Brawijaya Universities. The study was conducted from May to August 2016. The soil samples used in this study were taken from Kemirisewu village, Pandaan sub-district, Pasuruan district at a depth of $0-20 \mathrm{~cm}$. The waste of seaweed gel plant is obtained from PT. HAKIKI DONARTA, Pandaan Sub-district, Pasuruan Regency. The basic fertilizers used are Urea, $\mathrm{KCl}$, and TSP. Maize seeds used as indicator plants are hybrid varieties of BISI-2 corn. This study used Completely Randomized Design (RAL) with 4 (four) treatments and 3 (three) replications.

Addition of solid waste of seaweed with dosage of $15 \mathrm{Mg} / \mathrm{ha}$, increased of soil acidity and C-Organic content, besides also can increase Phosphorus and Potassium content available, Nitrogen, Phosphorus, and Potassium plant uptake, and the best growth of corn crops.
\end{abstract}




\section{Pendahuluan}

Inceptisol merupakan salah satu jenis ordo tanah yang tergolong luas penyebarannya di Indonesia. Persebaran Inceptisol tersebut mencapai kurang lebih hampir 52 juta hektar (Kasno, 2009). Inceptisol banyak digunakan sebagai lahan pertanian intensif, karena pengelolaannya kurang tepat, maka sebagian besar Inceptisol tingkat kesuburannya menjadi rendah. Hal tersebut ditunjukan oleh kemasaman tanah, kandungan bahan organik, dan nitrogen yang rendah. Menurut Munir (1996), Inceptisol adalah tanah yang tergolong masih muda atau tanah yang sedang mulai berkembang. Profil Inceptisol mempunyai horizon yang pembentukannya agak lambat sebagai hasil alterasi bahan induk. Tekstur tanah biasanya beragam dari kasar hingga halus, hal ini tergantung pada tingkat pelapukan dari bahan induknya. Bentuk lahan beragam dari berombak hingga bergunung. Kesuburan tanahnya rendah dikarenakan kandungan bahan organik tanah, kemasaman, dan kandungan beberapa unsur makro rendah. Di daerah dataran rendah pada umumnya memiliki solum tanah yang tebal, sedangkan di daerah yang belereng curam memiliki tingkat ketebalan solum yang tipis.

Berdasarkan penelitian

Nursyamsi dan Suprihati (2005), kandungan C-organik dan nitrogen total pada Inceptisol lebih rendah jika dibandingkan dengan Oxisol, Vertisol, dan Andisol. Inceptisol selain kemasaman tanahnya tergolong agak masam, kandungan basa yang dipertukarkan seperti $\mathrm{Ca}^{2+}, \mathrm{Mg}^{2+}, \mathrm{K}^{+}$dan kejenuhan basa juga termasuk rendah, selain itu kadar fosfor tersedia rendah. Untuk memperbaiki tingkat kesuburan Inceptisol salah satunya adalah dengan menambahkan bahan organik tanah. Permasalahan yang ada di tingkat petani, harga pupuk organik umumnya mahal dan sulit untuk mendapatkannya. Limbah padat pabrik agar-agar rumput laut berupa senyawa organik, mungkin dapat dimanfaatkan sebagai sumber pupuk organik tanah.

Menurut Afif (2011), rumput laut termasuk famili ganggang merah, yang dapat digolongkan menjadi dua kelompok yaitu Agarophyte dan Agaroidophyte. Agarophyte merupakan bahan baku yang dapat digunakan sebagai pembuatan agar-agar. Sedangkan Agaroidophyte sebagai produsen senyawa yang bersifat agar-agar. Agar- agar merupakan campuran polisakarida yang melalui ekstraksi dari dinding sel ganggang merah (Rhodophyta), khususnya genus Gracilaria,Gelidium amansii, Erucosa, Grateloupia filicina, Ulva lactuca dan Enteromorpha sp. Agar-agar tersusun dari senyawa polisakarida melalui dua unit molekul agarose dan agaropektin. Agar agar memiliki kemampuan dalam mengentalkan, membentuk gel, menstabilkan, dan memperbaiki tekstur makanan sehingga banyak industri makanan yang memanfaatkan dan mengolah agar-agar menjadi suatu produk makanan seperti jelly, ice cream, makanan kaleng (daging dan ikan), roti, permen, manisan dan selai (Hafiz, 2009).

Hasil samping dari proses pengolahan rumput laut menjadi agaragar berbentuk limbah agar. Hasil samping industri rumput laut yang merupakan sumber bahan organik yang belum banyak dimanfaatkan. Dari total bahan baku yang diolah, terdapat $65-70$ persen hasil samping industri yang dihasilkan oleh industri agar-agar setiap harinya (Hapsari, 2009). Biasanya hasil samping tersebut hanya dibiarkan menumpuk di lokasi penimbunan. Hasil samping industri rumput laut memiliki potensi untuk dijadikan sebagai sumber bahan organik tanah, karena kadar bahan 
organik hasil samping industri rumput laut mencapai 6,4 \% (Afif, 2011). Penambahan unsur hara dengan pengaplikasian bahan anorganik dinilai sebagai langkah alternatif dalam meningkatkan produktivitas tanaman. Berdasarkan uraian diatas perlu dilakukan penelitian guna memanfaatkan hasil samping industri rumput laut, untuk mendapatkan produksi tanaman jagung yang tinggi pada Inceptisol. Tujuan penelitian ini adalah : (1) Mengetahui pengaruh pemberian limbah padat industri agar-agar rumput laut terhadap sifat kimia Inceptisol dan (2) pertumbuhan tanaman jagung.

\section{Metode Penelitian}

Penilitian ini dilakukan di rumah kaca, analisis contoh tanah dan hasil samping industri rumput laut dilaksanakan di laboratorium kimia dan fisika tanah. Penelitian ini dilaksanakan pada bulan Mei hingga Agustus 2016. Bahan yang digunakan dalam penelitian ini adalah contoh tanah yang diambil dari Desa Kemirisewu, Kecamatan Pandaan, Kabupaten Pasuruan pada kedalaman 0$20 \mathrm{~cm}$. Hasil samping produksi rumput laut diperoleh dari PT. Hakiki Donarta, Kecamatan Pandaan, Kabupaten Pasuruan. Pupuk dasar yang digunakan adalah pupuk Urea, KCI dan TSP. Benih jagung yang digunakan sebagai tanaman indikator yaitu jagung hibrida varietas BISI-2.

Rancangan percobaan yang digunakan adalah Rancangan Acak Lengkap (RAL) dengan 4 (empat) perlakuan dan 3 (tiga) ulangan. Jenis perlakuan adalah : 1. Kontrol (tanpa penambahan hasil samping rumput laut). 2. Hasil samping rumput laut dosis 5 ton/ha. 3. Hasil samping rumput laut dosis 10 ton/ha. 4. Hasil samping rumput laut dosis 15 ton/ha. Dosis hasil samping industri rumput laut yang digunakan pada penelitian ini disesuaikan dengan kebutuhan tanaman jagung (Nursyamsi dan Suprihati, 2005).

Sebelum melakukan percobaan tanah dikering anginkan, kemudian ditumbuk dan diayak hingga lolos ayakan $2 \mathrm{~mm}$. Tanah dicampur dengan hasil samping industri rumput laut sesuai perlakuan dan dimasukkan kedalam polibag yang memiliki kapasitas $5 \mathrm{~kg}$. Tanah diinkubasikan selama satu minggu sebelum tanam. Selanjutnya media tanah tersebut dipindahkan kedalam pot plastik, benih jagung ditanam kedalam media sebanyak 3 benih/polibag. Pemberian pupuk dasar dengan dosis 150 $\mathrm{kg} / \mathrm{ha}$ Urea, $100 \mathrm{~kg} / \mathrm{ha} \mathrm{KCl}$ dan 100 $\mathrm{kg} / \mathrm{ha}$ TSP, dilakukan dengan menempatkan pupuk pada lubang disamping tanaman sedalam $10-15 \mathrm{~cm}$, lalu ditutup kembali dengan tanah. Pemeliharaan meliputi penyiraman dan penjarangan. Penyiraman dilakukan untuk mempertahankan kandungan air tanah pada kapasitas lapang.

Pengamatan perubahan sifat-sifat tanah dilakukan pada saat tanaman berumur 60 hari setelah tanam, meliputi kandungan Nitrogen, Fosfor, dan Kalium. Sedang pengamatan terhadap tanaman dilakukan pada umur 15, 45 dan 60 hari setelah tanam meliputi tinggi tanaman, jumlah daun dan bobot kering brangkasan. Data yang diperoleh kemudian dianalisis menggunakan analisis sidik ragam (Anova), untuk mengetahui keragaman pada setiap 
perlakuan digunakan uji $\mathrm{F}$ pada taraf 5\%, apabila terdapat pengaruh antar perlakuan maka akan dilanjutkan dengan uji BNT pada taraf 5\%. Kemudian untuk mengetahui keeratan hubungan antar parameter dilanjutkan dengan uji korelasi dan regresi dengan menggunakan software SPSS 20.

\section{Hasil dan Pembahasan}

\section{Sifat kimia tanah}

Berdasarkan hasil analisis sidik ragam, pemberian bahan organik yang berasal dari hasil samping industri rumput laut memberikan pengaruh nyata terhadap perubahan $\mathrm{pH}$ tanah. Sejalan dengan penelitian Afif (2011) bahwa pemberian hasil samping industri rumput laut berpengaruh nyata terhadap $\mathrm{pH}$ tanah. Hal tersebut dapat dikarenakan penambahan bahan organik yang berasal dari hasil samping industri rumput laut telah terdekomposisi, dan dapat mengakibatkan terjadinya pelepasan kation-kation basa. Rata-rata nilai $\mathrm{pH}$ pada setiap perlakuan dan pengamatan mengalami peningkatan. Sedangkan dari hasil penelitian Hapsari (2009), menyebutkan bahwa dengan penambahan bahan organik berupa kompos, dapat meningkatkan kandungan pH tanah. Imayawati (2006), menyatakan bahwa peningkatan $\mathrm{pH}$ dapat terjadi karena adanya proses protonasi dan deprotonasi hasil dekomposisi bahan organik yang selanjutnya akan berpengaruh terhadap konsentrasi ion $\mathrm{H}^{+}$pada larutan tanah.

$$
\text { Kadar C-organik yang }
$$

terkandung dalam tanah memiliki suatu peranan penting dalam menentukan kesuburan tanah baik itu dari segi fisik, kimia, maupun secara biologis tanah. Inceptisol yang berada di desa
Kemirisewu pada umumnya memiliki kandungan C-organik sangat rendah $(0,55 \%)$. Aplikasi dari hasil samping industri rumput laut memberikan pengaruh yang nyata terhadap kandungan C-organik tanah dan merubah status sangat rendah menjadi sedang. Hasil COrganik tanah yang paling tinggi terlihat akibat perlakuan, penggunaan hasil samping rumput laut 15 ton/ha, yakni memiliki tingkat kandungan C-Organik tertinggi sebesar 2,90\%. Hal tersebut sesuai dengan pernyataan Silohoy (2008), bahwa dengan pemberian bahan organik dapat menambah kandungan C-organik tanah. Disamping berpengaruh terhadap kemasaman tanah dan kandungan Corganik, penggunaan limbah padat pabrik agar-agar rumput laut juga dapat meningkatkan kandungan $\mathrm{N}$-total tanah walaupun hasilnya tidak nyata. Pemberian hasil samping industri rumput laut memberikan pengaruh yang nyata terhadap kandungan nitrogen total tanah. Sejalan dengan penelitian Hapsari (2009), bahwa pemberian hasil samping industri rumput laut tidak berpengaruh nyata terhadap nitrogen total tanah. $\mathrm{Hal}$ tersebut dapat disebabkan oleh karena dalam pembuatan agar-agar rumput laut dipanaskan sehingga banyak kandungan nitrogen yang hilang akibat menguap.

Hasil analisis sidik ragam, pemberian hasil samping industri rumput laut memberikan pengaruh yang nyata terhadap kandungan ketersediaan fosfor dan kalium dalam tanah. Kandungan fosfor tersedia dalam tanah tertinggi sebesar 72,2 ppm, sedang kandungan kalium tanah tertinggi $0.44 \mathrm{me} / 100 \mathrm{~g}$, terjadi akibat perlakuan pemberian limbah padat pabrik agar-agar rumpur laut dengan dosis 15 ton/ha. 
B. Siswanto dan Widowati/ Buana Sains Vol 18 No 1 : 57-66

Tabel 1. Pengaruh limbah padat pabrik agar-agar rumput laut terhadap sifat kimia tanah

\begin{tabular}{|l|l|c|c|c|c|c|}
\hline \multirow{2}{*}{ No } & \multirow{2}{*}{ Perlakuan } & \multicolumn{5}{|c|}{ Sifat kimia tanah } \\
\cline { 3 - 7 } & & C-org $(\%)$ & N-tot $(\%)$ & $\mathrm{P}(\mathrm{ppm})$ & $\mathrm{K}(\mathrm{me} / 100 \mathrm{~g})$ & $\mathrm{pH}$ \\
\hline 1 & Kontrol & $1,98 \mathrm{a}$ & $0,07 \mathrm{a}$ & $70,05 \mathrm{a}$ & $0,36 \mathrm{a}$ & $5,43 \mathrm{a}$ \\
\hline 2 & 5 ton/ha & $2,60 \mathrm{~b}$ & $0,07 \mathrm{a}$ & $71,32 \mathrm{~b}$ & $0,37 \mathrm{a}$ & $5,68 \mathrm{~b}$ \\
\hline 3 & 10 ton/ha & $2,62 \mathrm{~b}$ & $0.08 \mathrm{a}$ & $71,54 \mathrm{~b}$ & $0,43 \mathrm{~b}$ & $5,73 \mathrm{~b}$ \\
\hline 4 & 15 ton/ha & $2,90 \mathrm{c}$ & $0.08 \mathrm{a}$ & $73,29 \mathrm{c}$ & $0,44 \mathrm{~b}$ & $5,96 \mathrm{c}$ \\
\hline
\end{tabular}

Keterangan : nilai rata-rata yang didampingi huruf yang sama tidak berbeda nyata pada uji BNT 5\%.

\section{Pertumbuhan dan produksi berat kering tanam.}

Hasil analisis ragam menunjukkan adanya pengaruh yang nyata dari penambahan hasil samping industri rumput laut terhadap tinggi tanaman. Aplikasi hasil samping industri rumput laut yang memberikan pengaruh tertinggi pada parameter tinggi tanaman yaitu perlakuan hasil samping industri rumput taut 15 ton/ha yaitu rata-rata 122 $\mathrm{cm}$ pada umur 60 hari, sedangkan tinggi tanaman yang terendah yaitu rata-rata tinggi 71,97 cm, dihasilkan akibat perlakuan tanpa pemberian hasil samping industri rumput laut. Imayawati (2006), menyatakan bahwa pada fase vegetatif tanaman jagung telah menyerap 43\% dari nitrogen total yang tersedia pada tanah. Hasil fotosintesis pada fase ini lebih banyak ditranslokasikan untuk pembentukan sel-sel baru, perpanjangan sel dan penebalan jaringan.

Salah satu faktor yang mempengaruhi pertumbuhan tanaman yaitu jumlah daun yang terdapat dalam tanaman tersebut. Hal tersebut karena berketerkaitan dengan proses fotosintesis. Semakin banyak jumlah daun maka proses fotosintesis yang terjadi dalam tanaman semakin banyak. Aplikasi hasil samping industri rumput laut memberikan pengaruh yang nyata terhadap jumlah daun. Jika dibandingkan antara perlakuan pemberian hasil samping industri rumput laut dengan tanpa pemberian hasil samping produksi rumput taut bahwa jumlah daun terbanyak yaitu pada hasil samping industri rumput laut 15 ton/ha sebesar 14 daun. Berdasarkan hasil analisis ragam bahwa dengan penambahan bahan organik yang berasal dari hasil samping industri rumput taut berpengaruh nyata terhadap jumlah daun tanaman jagung. Menurut Hardjowigeno (2003) menyatakan bahwa bahan organik yang telah terurai menjadikan unsur hara yang berada dalam tanah yaitu Nitrogen, Fosfor, dan Kalium siap terserap oleh tanaman sehingga pertumbuhan tanaman seperti jumlah daun akan meningkat.

Aplikasi industri rumput taut memberikan pengaruh yang nyata terhadap berat kering tanaman. Jika berat kering tanaman diurutkan dari nilai tertinggi hingga terendah, maka pada perlakuan pemberian hasil samping industri rumput laut 15 ton/ha memiliki nilai tertinggi dari berat kering tanaman sebesar $8,79 \mathrm{~g} /$ tanaman. Nilai terendah dari berat kering tanaman yaitu pada perlakuan tanpa pemberian hasil samping industri rumput laut yakni sebesar 7,31 g/ tanaman. Senada dengan penelitian Rahayu (2008) bahwa bobot tanaman kering yang terendah yaitu pada perlakuan kontrol. Hal tersebut dapat dikarenakan pada perlakuan ini tidak ada penambahan unsur hara yang meliputi bahan organik, sehingga nutrisi hara yang dibutuhkan oleh tanaman kurang tersedia dan hasilnya menjadi rendah. 
B. Siswanto dan Widowati/ Buana Sains Vol 18 No 1 : 57-66

Tabel 2. Pengaruh limbah pabrik agar-agar rumput laut terhadap pertumbuhan tanaman jagung.

\begin{tabular}{|r|c|c|c|c|}
\hline \multirow{2}{*}{ No } & Perlakuan & \multicolumn{3}{|c|}{ Pertumbuhan } \\
\cline { 3 - 5 } & & Tinggi $(\mathrm{cm})$ & Jumlah daun & Bobot kering $(\mathrm{g})$ \\
\hline 1 & Kontrol & $67 \mathrm{a}$ & $8 \mathrm{a}$ & $8,31 \mathrm{a}$ \\
\hline 2 & $5 \mathrm{ton} / \mathrm{ha}$ & $88 \mathrm{~b}$ & $10 \mathrm{~b}$ & $9,30 \mathrm{~b}$ \\
\hline 3 & $10 \mathrm{ton} / \mathrm{ha}$ & $106 \mathrm{~b}$ & $12 \mathrm{~b}$ & $9,36 \mathrm{~b}$ \\
\hline 4 & $15 \mathrm{ton} / \mathrm{ha}$ & $132 \mathrm{c}$ & $14 \mathrm{c}$ & $11,79 \mathrm{c}$ \\
\hline
\end{tabular}

Keterangan : nilai rata-rata yang didampingi huruf yang sama tidak berbeda nyata pada uji BNT 5\%.

\section{Serapan N, P dan K.}

Aplikasi hasil samping industri rumput laut tidak berpengaruh nyata terhadap serapan nitrogen tanaman. Namun jika dibandingkan antara perlakuan penambahan hasil samping industri rumput laut dan tanpa penambahan hasil samping industri rumput laut, menunjukan bahwa serapan nitrogen yang tertinggi dihasilkan oleh perlakuan penambahan industri rumput laut dosis 15 ton/ha yakni sebesar 14,24 $\mathrm{g} /$ tanaman. Kondisi ini karena pengaruh penambahan limbah padat pabrik agaragar rumput laut, tidak memberikan pengaruh nyata terhadap kandungan $\mathrm{N}$ total tanah. Pemberian hasil samping industri rumput laut memberikan pengaruh nyata terhadap serapan fosfor tanaman. Perlakuan penambahan hasil samping industri rumput laut dengan dosis 15 ton/ha menghasilkan serapan fosfor yang tertinggi sebesar $1.09 \mathrm{~g} /$ tanaman. Nurdin et al., 2009, menyatakan bahwa peningkatan serapan fosfor tanaman dapat dipengaruhi oleh besarnya fosfor tersedia pada tanah sehingga dapat meningkatkan pertumbuhan tanaman. Disamping karena pengaruh kandungan Phorphor tersedia, ketersediaan fosfor dalam tanah dapat juga dipengaruhi oleh $\mathrm{pH}$ tanah. Ispandi (2004) mengemukakan bahwa peningkatan kadar fosfor tersedia di dalam tanah dapat berasal dari pelapukan bahan organik dan tergantung oleh pH tanah.

Perlakuan penggunaan hasil samping industri rumput laut 15 ton/ha menghasilkan serapan kalium sebesar 15,91 g/tanaman. Hasil analisis sidik ragam menunjukkan bahwa dengan semakin besar dosis aplikasi hasil samping industri rumput laut, memberikan pengaruh yang nyata terhadap serapan kalium tanaman. Peningkatan serapan kalium tanaman diduga karena kandungan kalium tersedia dalam tanah. Hal ini dikarenakan ketersediaan kalium dalam tanah dalam bentuk kalium terlarut berada pada kondisi yang seimbang antara kalium dapat dipertukarkan dan kalium tidak dipertukarkan, kalium tidak dipertukarkan yaitu kalium terfiksasi dan kalium struktural (Ispandi, 2004). Bentuk kalium dapat dipertukarkan merupakan bentuk kalium yang cepat tersedia atau Kalium aktual. Sedangkan kalium tidak dapat dipertukarkan yaitu bentuk kalium yang lambat tersedia atau disebut kalium potensial.

\section{Hubungan beberapa parameter.}

Berdasarkan hasil korelasi bahwa kadar C-organik dalam tanah memiliki keeratan hubungan yang nyata terhadap kandungan Kalium tersedia tanah sebesar $\mathrm{r}=0,91^{* *}$. Sedangkan hasil regresi antara $\mathrm{C}$-organik dengan kalium tersedia 
tanah diperoleh persamaan $\mathrm{Y}=0,14+$ $0,10 \mathrm{X}$, dengan niulai koefisien regresi sebesar $\mathbf{R}^{2}=0,83$. Hal ini menunjukkan bahwa kadar C-organik tanah mempengaruhi kalium tersedia dalam tanah. Ispandi 2004, menyatakan bahwa terdapat beberapa faktor yang mempengaruhi ketersediaan $\mathrm{K}^{+}, \mathrm{Ca}^{2+}$ clan $\mathrm{Mg}^{2+}$ yaitu kandungan bahan organik, tipe dari mineral liat, KTK, dan lengas tanah. Bentuk ion $\mathrm{K}^{+}$didalam tanah dapat berubah dari bentuk tidak tersedia menjadi bentuk tersedia dan juga sebaliknya. Diduga bahwa kandungan Corganik yang terdapat didalam hasil samping industri rumput laut memberikan pengaruh terhadap ketersediaan kalium dalam tanah. Selanjutnya tingkat ketersediaan kalium sangat mempengaruhi besarnya serapan kalium tanaman. Hal ini dibuktikan dengan tingginya tingkat korelasi antara kalium tersedia dengan serapan kalium yaitu $\mathrm{r}=0,79 *$. Hasil regresi antara serapan kalium tanaman dengan kalium tersedia tanah diperoleh persamaan $\mathrm{Y}=$ 9,35 + 56,02 X dan menunjukkan hasil yang kuat $\left(\mathrm{R}^{2}=0,63\right)$. Peningkatan dosis pemberian hasil samping industri agaragar rumput laut meningkatkan ketersediaan kalium pada tanah. Dengan peningkatan ketersediaan kalium pada tanah mempengaruhi peningkatan serapan kalium pada tanaman. Hal ini selaras dengan penelitian Silahooy (2008), bahwa dengan pengaplikasian dosis $\mathrm{K}^{+}$ dapat meningkatkan serapan kalium pada tanaman. Konsentrasi kalium dalam larutan tanah merupakan salah satu faktor seberapa besar jumlah kalium yang diserap oleh tanaman. Semakin tinggi konsentrasi kalium tanah maka serapan kalium tanaman juga semakin tinggi.

Selain itu terdapat nilai korelasi yang sangat kuat antara serapan kalium tanaman dengan tinggi tanaman sebesar $\mathrm{r}$ $=0,99 * *$. Serapan kalium tanaman memiliki keeratan hubungan yang kuat dengan tinggi tanaman. Hasil regresi antara serapan kalium dengan tinggi tanaman diperoleh persamaan $\mathrm{Y}=22,50$ $+5,77 \mathrm{X}$ dan menunjukkan hasil yang sangat kuat $\left(R^{2}=0,98\right)$. Sesuai dengan hasil penelitian yang dilakukan oleh Amilcar (2013), bahwa semakin tinggi status hara kalium tanah, maka kebutuhan tanaman akan hara kalium semakin tercukupi sehingga dapat menghasilkan pertumbuhan tanaman yang semakin tinggi. Dalam penelitian Silahooy (2008), mengungkapkan bahwa perlakuan kalium terhadap tinggi tanaman berhubungan dengan meningkatnya ketersediaan kalium, dan serapan kalium tanaman. Pada sisi lain hasil korelasi antara serapan kalium dengan jumlah daun didapatkan hasil yang kuat yaitu $r=0,86^{* *}$. menunjukkan bahwa hasil regresi antara serapan kalium dengan jumlah daun diperoleh persamaan $\mathrm{Y}=7,6467+0,3514 \mathrm{x}$ dan menunjukkan hasil yang kuat yaitu sebesar $R^{2}=0,74$. Jumlah daun merupakan parameter pertumbuhan vegetatif tanaman karena dapat dijadikan sebagai data penunjang untuk menjelaskan proses pertumbuhan yang terjadi.

Pada analisis sidik ragam menjelaskan bahwa terdapat pengaruh pemberian hasil samping rumput laut yang nyata terhadap rerata jumlah daun. Pemberian bahan organik tersebut mempengaruhi kandungan kalium tersedia tanah sehingga dapat meningkatkan jumlah serapan kalium tanaman. Pada fase vegetatif kebutuhan akan kalium jauh lebih besar dari pada kebutuhan fosfor, sebab kalium penting dalam pembentukan daun sedangkan fosfor penting dalam pembentukan biji. Biasanya kebutuhan total unsur hara kalium untuk pertumbuhan tanaman mencapai 3 hingga 4 kali kebutuhan 
fosfor. Selain itu serapan kalium oleh tanaman juga mempengaruhi berat kering tanaman. Hal tersebut dibuktikan dengan adanya nilai korelasi yang kuat antar kedua parameter tersebut sebesar $\mathrm{r}=$ 0,96**. Hasil regresi antara serapan kalium tanaman dengan berat kering tanaman diperoleh persamaan $\mathrm{Y}=5,53$ $+0,20 \mathrm{X}$ dan menunjukkan hasil yang sangat kuat $\left(R^{2}=0,92\right)$. Hal ini sejalan dengan penelitian yang dilakukan oleh Nurdin et al. (2009) bahwa dengan penambahan unsur hara kalium seperti pemberian pupuk KCI dengan dosis 75 $\mathrm{kg} / \mathrm{ha}$ berpengaruh nyata terhadap berat kering tanaman jagung dan menghasilkan bobot kering 7,53 g. Berat kering tanaman merupakan perhitungan berat organ-organ tanaman. Apabila tanaman tersebut tinggi dan memiliki jumlah daun yang banyak maka dapat diasumsikan berat kering tanaman akan tinggi juga. Nilai korelasi antara parameter tinggi tanaman dengan berat kering tanaman yaitu $\left(r=0,98^{* *}\right)$. Sedangkan nilai korelasi antara jumlah daun dan berat kering tanaman sebesar $r=0,88^{*}$. Hasil regresi antara tinggi tanaman dan berat kering tanaman diperoleh persamaan $\mathrm{Y}=$ $4,82+0,03 \mathrm{X}$ dan menunjukkan hasil yang sangat kuat $\left(R^{2}=0,97\right)$. Sedangkan pada analisis regresi antara jumlah daun dan berat kering tanaman diperoleh persamaan $\mathrm{Y}=2,82+0,43 \mathrm{X}$ serta menunjukkan hasil yang kuat $\left(\mathrm{R}^{2}=0,77\right)$. Pengamatan berat kering tanaman merupakan salah satu parameter untuk mengetahui pertumbuhan vegetatif tanaman. Pengukuran dari berat kering tanaman merupakan bagian dari pengukuran biomassa tanaman.

\section{Kesimpulan}

Penggunaan limbah padat hasil samping industri agar-agar rumput laut dengan dosis 15 ton/ha, meningkatkan $\mathrm{pH}$ tanah dari 5.43 menjadi 5,96 dan kandungan C-Organik tanah dari 1,98 menjadi $2,90 \%$. Selain itu juga dapat meningkatkan fosfor tersedia tanah dari 70,05 menjadi 73,29 ppm, sedangkan untuk kalium tersedia tanah dari 0,36 menjadi $0,44 \mathrm{me} / 100 \mathrm{~g}$, demikian pula terhadap serapan Nitrogen (14,24 g/tanaman), serapan Fosfor (1,09 g/tanaman), serapan Kalium tanaman $(15,91 \mathrm{~g} /$ tanaman $)$.

Pemberian bahan organik yang berasal dari hasil samping industri agaragar rumput laut dengan dosis 15 ton/ha menghasilkan pertumbuhan tanaman yang terbaik dengan ditunjukan oleh tinggi tanaman, jumlah daun, dan berat kering tanaman tertinggi.

\section{Daftar Pustaka}

Afif AK. 2011. Pemanfaatan Limbah Padat Proses Pengolahan Agar PT Agarindo Bogatama Sebagai Media Tanam Holtikultura. Skripsi. Bogor : Fakultas Perikanan dan Ilmu Kelautan, Institut Pertanian Bogor.

Amilcar, A. 2013. The Potential Benefits for Controlled Release Phosphorus and Potassium in Specialty Agriculture. Third International Conference on Slow and Controlled Release and Stabilized Fertilizers. Rio de Janeiro. Brazil. 
Duaja, W. 2012. Pengaruh Pupuk Urea, Pupuk Organik Padat dan Cair Kotoran Ayam Terhadap Sifat Tanah, Pertumbuhan dan Hasil Selada Keriting di Tanah Inceptisol. Jurnal. Vol 1 No.4 Oktober-Desember 2012. ISSN : 23026472

Hafiz A. 2010. Mempelajari pemanfaatan limbah padat Pabrik Agar - Agar Untuk Menunjang Stabilitas Struktur Tanah. Skripsi. Fakultas Teknologi Pertanian, Universitas Brawijaya. Malang

Hapsari, O. 2009. Pengaruh Pemberian Kompos Kombinasi Daun Lamtoro (Leucaena Diversifolia) Dengan Kotoran Ayam Terhadap Ketersediaan Dan Serapan Serta Pertumbuhan Tanaman Jagung (Zea Mays L) Sebagai Indicator Pada Entisol Wajak, Kabupaten Malang. Skripsi. Universitas Brawijaya. Malang

Hardjowigeno, S. 2003. Klasifikasi Tanah dan Pedogenesis. edisi baru. Mediatama sarana persada. Jakarta

Imayawati. 2006. Pengaruh Pemberian Kompos Sampah UNIBRAW dan Kotoran Sapi Terhadap Ketersediaan dan Serapan N Serta Pertumbuhan Tanaman Jagung (Zea Mays L.) Pada Entisol Wajak Malang. Skripsi. Uniersitas Brawijaya. Malang.

Ispandi, A., A. Munip. 2004. Efektivitas Pupuk PK dan Frekuensi Pemberian Pupuk K Dalam Meningkatkan Serapan Hara dan Produksi Kacang Tanah di Lahan
Kering Alfisol. Hal. 151-161. Malang

Kasno, A. 2009. Respon Tanaman Jagung Terhadap Pemupukan Fosfor Pada Typic Dystrudepts. J. Tanah Tropika 14(2):111-118.

Mandela. 2010. Pengaruh Pupuk Limbah Agar-Agar Terhadap

Pertumbuhan Semai Mahoni (Swietenia macrophylla, King) di Media Tailing Tambang Emas PT Antam UBPE Pongkor). skripsi. Fakultas Perikanan dan Ilmu Kelautan. Insitut Pertanian Bogor. Bogor

Munir, M. 1996. Tanah-Tanah Utama Indonesia. PT Dunia Pustaka Jaya. Jakarta Novizan.2002. Petunjuk Pemupukan yang Efektif. Agromedia Pustaka. Jakarta.

Nurdin., P. Maspeke., Z. Ilahude., dan F. Zakaria. 2009. Pertumbuhan dan hasil Jagung yang dipupuk N, P dan K pada tanah Vertisol Isimu Utara Kabupaten Gorontalo. J. Tanah Trop. 14 (1): $49-56$.

Nursyamsi, D dan Suprihati. 2005. SifatSifat Kimia dan Mineralogi Tanah Serta Kaitannya Dengan Kebutuhan Pupuk Untuk Padi (Oryza sativa), Jagung (Zea mays), dan Kedelai (Glycine max). Bul. Agron. (33) (3) 40-47

Rahayu, R D. 2008. Pengaruh Pemanfaatan Bahan Organik Paitan (Tithonia Diversifolia), Kotoran Ayam, Kotoran Sapi, Dan Lumpur Lapindo Terhadap Ph Tanah Dan Kation Basa (Dd) Serta Pertumbuhan Tanaman 
Jagung (Zea Mays L) Pada

Inceptisol Porong Sidoarjo.

Universitas Brawijaya Malang

Silahooy, Ch. 2008. Efek Pupuk KCI dan

SP-36 Terhadap Kalium

Tersedia, Serapan Kalium dan

Hasil Kacang Tanah (Arachis

hypogaea L.) pada Tanah

Brunizem. Bul. Agron. (36)(2)

126-132 